\title{
Revitalization of Green Open Space to Fulfill the Needs of Urban Communities
}

\author{
Muhammad Rezky Noor Handy ${ }^{1 *}$ Indra Maulana ${ }^{1}$ \\ ${ }^{1}$ Social Studies Education, Faculty of Teacher Training and Education, Lambung Mangkurat University, Banjarmasin, \\ Indonesia \\ *Corresponding author. E-mail: rezky.handy@ulm.ac.id
}

\begin{abstract}
Green open space is very vital in today's city development. The need for a public area by the community for their various daily activities. This article aims to see the importance of green open space in meeting the needs of urban communities in carrying out their various activities. Seeing the construction of new parks or green open spaces, the legacy will be continued for the next generation, with designs that will be used for years to come by urban communities, as well as in tackling air pollution. Later, he will see the development of green open space development in line with the needs of urban communities for public spaces that can be used for various activities.
\end{abstract}

Keywords: Green open space, urban communities, and activities.

\section{INTRODUCTION}

Indonesia, which has a population of nearly 270 million and occupies the 4th ladder in the world for its population in 2020, is now spread out from Sabang to Merauke. Various modern human activities now often result in very significant changes, especially in environmental problems. The environment in this modern era is very risky, climate change caused by deforestation is getting worse, illegal logging, mining activities (coal, sand, mountain rocks, gold, and others), besides that the land clearing by farmers by burning land is also very influential, besides that there is also a lot of disposal of both household waste and toilets or bathing, washing, latrines and also family liquid waste (Faeces, Urine, Gray Water), industry or waste from the daily activities of the community itself to the environment makes various kinds of pollution both land, water and air [1].

This very chaotic urban development planning makes urban areas become less neatly arranged so that the needs of urban communities for these beautiful open places to simply release the fatigue of a walk with family, exercise or other activities are very inadequate, urban conditions are like this is very necessary with long-term development, so that the community itself can use the area. The government finally launched the development of urban areas with the obligation to have green areas, one of which is the Green Open Space (RTH).

Currently, the need to create open green areas is unquestionable. Their value is demonstrated through their use for recreational, sports, cultural and socio-economic, ecological, and especially biodiversity purposes, which has always been considered one of the most important factors in recent years, as well as in the future $[2,3,4]$. This article aims to see that with the construction of new parks or green open spaces (RTH), the legacy will be continued for the next generation, with designs that will be used for years to come by urban communities, becoming a vital necessity for urban communities today.

\section{METHODS}

This research uses library research, by referring to the theories of experts about a problem. The objective of this study is to examine texts, books, and publications on local culture from relevant bibliographical texts that are raised as problems in this research topic. The data source used is data from the relevant previous research results. The steps taken include collecting library data, reading, taking notes, and comparing literature then processed to produce conclusions. The data used are secondary data from textbooks, journals, scientific articles, and literature reviews that contain the concepts being studied [5].

\section{RESULT AND DISCUSSION 3.1 Green Open Space (RTH) in City Development Planning}

RTH or Green Open Space according to Law Number 26 of 2007 concerning Spatial Planning in article 1 paragraph 31 states that Green Open Space is an area that extends or lanes and/or in groups, whose use is more open as a place to grow plants, whether they grow naturally or intentionally planted. The existence of Green Open Space is an important element in forming a comfortable and healthy urban environment. Aiming at maintaining the beauty of the city and the means of protecting the urban environment, besides that, apart from being a protected area, RTH also functions socially as an open public space for social interaction in the community such as recreation areas, sports facilities, and/or play areas. This green space must have good accessibility for everyone, including accessibility for people with disabilities. Besides, it is also stated in the Law on spatial planning, Article 29, among others, has explicitly mandated that $30 \%$ of the 
city/urban area must be in the form of Green Open Space (RTH), with a composition of $20 \%$ Public RTH and $10 \%$ Private RTH $[6,2,7]$.

Revitalization of green areas (Green Areas) by 30\% both public and private green open space. The development of cities, in this case, is reflected in the relatively high density of buildings, sporadic and diffuse urban growth, unclear and non-patterned city structures, relatively low quality of city views, and various other urban problems. With these conditions, it seems difficult to change the existing urban pattern into a quality city and can optimally play a role in driving regional economic growth. The implementation of urban rejuvenation programs will certainly require high economic and social costs, while the results will not be optimal, especially in the development of green areas (Green Areas). Besides, the Green Structure step is the act of creating a structure and utilizing forms that are natural and effective assets, all through the life cycle of a structure. This includes everything from sitting down to planning, development, activity, support, overhaul, destruction; and everything from the decision on building materials to where the structure is developed next, with the basis for the development of environmental improvements, whether the construction of new parks or changing land functions into green open spaces by the local government - apart from that as green infrastructure for cities, this green open space is an ecological framework. for environmental sustainability. Therefore, the construction of city squares or other areas as green infrastructure is a network of urban green open space to protect the value and function of natural ecosystems that can provide positive support for human life $[8,6,3,9,10,4]$.

\subsection{Urban Community Needs for A Green Open Space}

The need for green open areas apart from local governments is competing to achieve a minimum of $30 \%$ as a requirement to participate in Adipura, with the criteria for the selection of the city of Adipura divided into two main indicators, namely physical indicators in the form of urban environmental conditions which include cleanliness and shade of the city as well as non-indicators. -physically in the form of urban environmental management, therefore local governments throughout Indonesia are competing to organize their respective cities with the development of green areas and Green Open Space is one of the vital plans for the development of urban areas at this time, in addition to the environmental management itself by educating the community about the importance of protecting the environment. Seeing this, it becomes a trigger for the importance of Green Open Space (RTH) for the community, both for small cities and even metropolitan cities, not only as just a complement to urban development and are always faced with the interests of developing urban economic interests by some groups $[11,12,13]$.

Saw from the busyness of urban communities in this modern era, it requires various treatments to get rid of fatigue, one of which is the need for green open space (RTH) for activities during weekend holidays or, how important the development of RTH is, apart from being a fulfillment, it must also invite people not to there is an overlap of land use or areas that should be used for other public facilities and which areas are used as green open spaces in cities, so that urban development planning and meeting the needs of urban communities will be more coherent and can run smoothly, especially this public space can become urban tourist destinations that are designed in such a way, contribute to the development of the economy of the community around these public spaces, ideas that can provide development both of facilities and infrastructure, besides that to empower that public spaces, especially green open spaces. This can be done by providing steps such as the following, 1) investing in the construction of urban facilities and infrastructure, especially (toilets, lampposts, notification boards, trash bins, large and safe parking lots, or provision of wifi spots); 2) carry out regular planning, development and management of the government and society so as to maintain this green open space to protect the environment and reduce air pollution; 3) provide training and empowerment regarding supporting economic activities around the public area; 4) provide outreach to the surrounding community regarding the management and empowerment of public areas. So that by meeting the need for this green open space area, the community can use the facilities provided by the government, besides that they are also able to maintain especially manage it so that it can last a long time and support development planning for the convenience of everyone. Green open space (RTH), which has been used by the community or is still in the planning stage, is expected to be able to prepare public facilities, child-friendly play areas, jogging tracks, educational areas (such as those in Banjarmasin City Traffic Park, Banjarbaru City Smart Park), green plants to support the greening of urban areas, the availability of wifi spots for the community, usually, there are also mascots or monuments, monuments or statues typical of the city (such as the Bekantan Statue in the siring of Banjarmasin City, the Bawang Monument in RTH Ex Rantau Market, Tapin), or also the development of the river-based tourism sector in the city of Banjarmasin such as Lok Baintan Floating Market and Siring Tendean Modern Floating Market. Although there are still many cities in Indonesia that have not reached the minimum limit for the needs of Green Areas, it is now a reference for the main plan in urban planning and development throughout Indonesia $[14,15]$.

\section{CONCLUSION}

This green open space $(\mathrm{RTH})$ is a necessity for very vital urban communities, especially urban areas, to become a public area that is greatly used by the community to relieve fatigue after work, take a walk with family or exercise there, urban areas with minimal green areas (green areas) this is how vital the development of green open spaces is. Also, it is hoped that green open space from any urban area development planning carried out by the respective regional governments, which in turn can have an impact on both the wider community and the surrounding environment both as a fulfillment of the need for public space as a means of the activity or as a container or means of pollution reduction air. 


\section{REFERENCES}

[1] A. Sumantri, Kesehatan Lingkungan - Edisi Revisi. Prenada Media, 2017.

[2] M. M. Sudarwani and Y. D. Ekaputra, "Kajian Penambahan Ruang Terbuka Hijau di Kota Semarang," J. Tek. Sipil dan Perenc., vol. 19, no. 1, pp. 47-56, 2017, doi: 10.15294/jtsp.v19i1.10493.

[3] J. Georgi and P. Z. Zanou, "Analysis of the urban green areas of Nicosia: the case study of Linear Park of Pedieos River," no. September, p. 66, 2017, doi: 10.1117/12.2279665.

[4] S. İnançoğlu, Ö. Özden, and C. Kara, "Green corridors in urban landscapes, case study nicosia pedieos river," Eur. J. Sustain. Dev., vol. 9, no. 1, pp. 1-8, 2020, doi: 10.14207/ejsd.2020.v9n1p1.

[5] M. Zed, Metode Penelitian Kepustakaan. Jakarta: Metode Penelitian Kepustakaan, 2004.

[6] R. Dwihatmojo, "Ruang Terbuka Hijau Yang Semakin Terpinggirkan," 2016, doi: 10.1007/s00205-016-1019-6.

[7] S. Rijal, "KEBUTUHAN RUANG TERBUKA HIJAU DI KOTA MAKASSAR TAHUN 2017,"

J. Hutan dan Masy., vol. 3, no. 1, pp. 001-110, 2008.

[8] M. F. Mohd Sam, M. N. H. Tahir, I. Rajiani, and N. Muslan, "Green Technology Compliance in Malaysia for Sustainable Business," J. Glob. Manag., vol. 2, no. 1, pp. 55-65, 2011.

[9] S. Sari, I., Hidayat, T., Biyatmoko, D., \& Suyanto, "Peran dan Fungsi Ruang Terbuka Hijau Rantau Baru di Kota Rantau Kabupaten Tapin," Enviro Sci., vol. 15, no. 2, pp. 317-326, 2019, doi: 10.1017/CBO9781107415324.004.
[10] A. Aziz, Antariksa, and H. Santosa, "RUANG TERBUKA PUBLIK SEBAGAI ELEMEN INFRASTRUKTUR HIJAU KAWASAN KOTA (STUDI KASUS: ALUN-ALUN KABUPATEN PONOROGO) (Public Open Space as a Green Infrastucture Element in the City Region Case Study: Ponorogo District Square)," Jamang, vol. 1, no. 1, pp. 47-55, 2019, [Online]. Available: https://journal.umbjm.ac.id/index.php/jamang/.

[11] I. Meviana, L. Y. Irawan, and D. Kurniawati, "Persepsi Masyarakat Terhadap Revitalisasi RTH di Kota Malang," in Prosiding Seminar Nasional Pemanfaatan Informasi Geospasial untuk Peningkatan Sinergi Pengelolaan Lingkungan Hidup, 2016, pp. 1-5, [Online]. Available: http://repository.unikama.ac.id/1523/1/FullPaper-SeminarS2PKLH-UNS-Ika.pdf.

[12] S. Supratiwi, "Studi ruang terbuka hijau dalam kebijakan pengelolaan lingkungan hidup Pemerintah Kota Semarang," J. Ilm. Ilmu Pemerintah., vol. 3, no. 2, pp. 89-96, 2018, doi: 10.14710/jiip.v3i2.3878.

[13] W. Luthfi, "Beda Penghargaan Adipura, Adiwiyata dan Kalpataru," 2019. [Online]. Available:

https://www.goodnewsfromindonesia.id/2019/12 /02/beda-penghargaan-adipura-adiwiyata-dankalpataru pada 15 Maret 2020.

[14] E. W. Ajidayanti, A., \& Abbas, "Utilization of Tourism Bekantan Mascot as a Learning Resource On Social Studies," Innov. Soc. Stud. J., vol. 1, no. 1, pp. 78-86, 2019.

[15] E. W. Abbas, M. Rezky, and N. Handy, "Ecotourism of Martapura River Banjarmasin as a Learning Resources on Social Studies," Innov. Soc. Stud. J., vol. 1, no. March, pp. 111-119, 2020. 